\title{
Apoptosis-linked in vivo regulation of the tissue transglutaminase gene promoter
}

\author{
É Szegezdi', Z Szondy ${ }^{1}$, L Nagy ${ }^{1}$, Z Nemes ${ }^{2}$, RR Friis ${ }^{3}$, \\ PJA Davies ${ }^{4}$ and L Fésüs ${ }^{*, 1}$ \\ 1 Department of Biochemistry and Molecular Biology, University of Debrecen, \\ Debrecen, Hungary \\ 2 Department of Pathology, University of Debrecen, Debrecen, Hungary \\ 3 Laboratory of Clinical and Experimental Research, University of Bern, \\ Switzerland \\ ${ }^{4}$ Department of Integrative Biology and Pharmacology, University of Texas at \\ Houston, Houston, Texas, USA \\ * Corresponding author: L Fesus, Department of Biochemistry and Molecular \\ Biology, Medical Faculty, University of Debrecen, Nagyerdei krt. 98. H-4012, \\ Debrecen, Hungary. E-mail: fesus@indi.dote.hu
}

Received 23.5.00; revised 11.7.00; accepted 1.8.00

Edited by A Jetta

\begin{abstract}
Tissue transglutaminase (tTG) is upregulated in various cells undergoing apoptosis. To investigate the transcriptional regulation of $\mathrm{tTG}$ a mouse strain carrying a $\beta$-galactosidase reporter gene under the control of a 3.8 kilobase fragment of the tTG promoter was characterised. The transgene construct was shown to be expressed in the apoptotic regions of the mouse embryo. Here we report that the regulation of the transgene is also apoptosis-linked in adult animals. The transgene is induced in endocrine apoptosis involving mammary gland involution and corpus luteum regression. Induction of the reporter gene is detectable during in vivo but not in vitro apoptosis of thymocytes induced by the glucocorticoid receptor, the nur77, p53 and the retinoid receptor $\gamma$ mediated pathways. Additionally, the lacZ expression mimics the activation of the endogenous promoter in tissues characterised by high apoptotic turnover. These results suggest that the apoptosis-specific transcriptional regulation of tTG is mediated through elements of a $3.8 \mathrm{~kb}$ promoter and may require cosignals available only in tissue environment. Cell Death and Differentiation (2000) 7 , $1225-1233$.
\end{abstract}

Keywords: transglutaminase promoter; transgene mouse; apoptosis

Abbreviations: ANZ, anterior necrotic zone; DTT, dithiotreitol; EDTA, ethylenediamine tetraacetic acid; FCS, foetal calf serum; $\mathrm{IAP}$, inducer of apoptosis protein; $\mathrm{NF} \kappa \mathrm{B}$, nuclear factor $\kappa \mathrm{B}$; PNZ, posterior necrotic zone; RAR, retinoic acid receptor; RARE, retinoic acid response element; $R L U$, relative light unit; $R X R$, retinoid $X$ receptor; TCR, T-cell receptor; TGF $\beta$, transforming growth factor $\beta$; tTG, Tissue transglutaminase; TUNEL, terminal uridine nucleotide end labelling; X-gal, 5-bromo 4-chloro 3-indolyl $\beta$-D-galactopyranoside

\section{Introduction}

Apoptosis is a physiological process to eliminate unwanted cells. As a result of intense research activities of the last couple of years many molecular aspects of this active cell death process have been revealed including the existence of different apoptosis signalling pathways and the crucial role of caspases and the mitochondrion. It has been proposed that in living cells all the elements of the death machinery are constitutively expressed, but their action is suppressed by the presence of survival factors. ${ }^{1}$ However, there are several sets of data suggesting that the initiation of apoptosis in many tissues depends upon the expression of new genes. ${ }^{2-4}$ Furthermore, the activation of a number of nuclear receptors (e.g. steroid, thyroid, retinoid receptors) and p53 initiates apoptosis through transcriptional regulation. ${ }^{5-8}$ Even enzymes, closely related to the execution of death-such as caspases and endonucleases-may be induced upon the appearance of death signals. ${ }^{9,10}$ One such inducible enzyme of apoptosis is tissue transglutaminase.

Members of the transglutaminase enzyme family catalyse the calcium dependent posttranslational modification of proteins by crosslinking polypeptide chains through their glutaminyl and lysyl residues. ${ }^{11}$ These isopeptide bonds make protein polymers stable and resistant to enzymatic, chemical and mechanical disruption. One member of the transglutaminase family is tTG that is present in various cell types. In embryos this enzyme is expressed during chondrogenesis, in developing heart, liver and choroid plexus. ${ }^{12}$ In adults the enzyme displays high concentrations in erythrocytes, activated macrophages, endothelial cells and smooth muscle cells. ${ }^{13}$ It crosslinks extracellular matrix proteins, like fibrin, fibronectin, vitronectin, entactin and osteopontin during cartilage differentiation and wound healing. ${ }^{14,15}$ It also functions as a G-protein deemed necessary in transducing signals via the $\alpha_{1}$ adrenergic receptor to phospholipase $C,{ }^{16}$ and possibly participates in the regulation of cell growth and proliferation by modifying the retinoblastoma protein. ${ }^{17}$ The apoptosis of many cell types, including hepatocytes, thymocytes and epithelial cells of the involuting mammary gland has also been associated with the induction of tTG expression. It has been concluded that the enzyme is induced and activated in most forms of physiological cell death, particularly in cell death during morphogenesis and endocrine regulated tissue remodelling. ${ }^{18}$

The finding that tTG is induced in various forms of apoptosis has provided a tool to learn about the regulation of the inducible genes of apoptosis in vivo. For this purpose two founder lines of a transgenic mouse strain (TG26 and TG27) carrying the 3.8 kilobase fragment of the tissue transglutaminase promoter coupled to $\beta$-galactosidase reporter enzyme were characterised. ${ }^{19}$ It has been previously shown that the transgene displays specific pattern of expression during limb development. It is 
expressed in cartilage, the cells of the apical ectodermal ridge, and in regions of apoptotic cell death of the interdigital mesenchyme. While, however, there was a general agreement between the expression of the transgene and the endogenous transglutaminase at regions of chondrogenesis and sites of apoptosis of limb, no expression of the transgene was found in embryonic heart and liver where high tTG expression was detected. It was also shown that the expression of the reporter gene is much lower and consequently more restricted in the TG26 lineage possibly due to the different integration sites or to the different number of integrated transgene copies.

The aim of the present experiments was to study the expression pattern driven by this promoter fragment in different tissues of grown-up animals, in particular in tissues where high rate of apoptosis can be induced by various signalling pathways. Here we show that the transgene construct is active in adult mice. The introduced promoter fragment is capable of stimulating the reporter enzyme expression in tissues characterised by high apoptotic turnover, in the thymus in response to different apoptotic signalling pathways, in involuting mammary gland and during corpus luteum regression. Furthermore, the construct is not induced in thymocytes undergoing apoptosis under in vitro conditions strengthening the suggestion that in vivo studies are required to understand the full biological program of apoptosis.

\section{Results}

\section{Activity of the transglutaminase reporter construct in the thymus of transgenic mice}

Transgenic mice TG26 and TG27 carrying the $3.8 \mathrm{~kb}$ fragment of the $\mathrm{tTG}$ promoter ${ }^{19}$ were successfully bred in our laboratory. Because all the previous studies were carried out in embryonic age of these mice, in the first phase of our studies we had to determine whether the introduced transgene construct was active in grown up animals. In order to gain answer to this question, the thymus and its involution process were chosen as a model. In the experiments four weeks old TG27 mice were used, because at this age the endogenous TTG expression is easily detectable in the thymus and can be induced by glucocorticoids $^{7}$ (Figure 1A). All the experiments were conducted on transgene carrying and wild-type littermates (non-carriers) in order to exclude any aspecific result.

The expression of the reporter gene was monitored both at $\mathrm{mRNA}$ and protein level. The transcripts of the lac $Z$ gene were detectable by RT-PCR (3rd lane in Figure 1B). The expressed enzyme protein was also detectable by ELISA technique (Figure 1C). Additionally the reporter enzyme activity could also be measured $(48100 \pm 4120 \mathrm{RLU} / \mathrm{h} / \mathrm{mg}$ protein after subtracting the value of the non-carriers) (Figure 1D). These results undoubtedly prove that the transgene construct can be active in adult mice.

To ascertain whether the reporter construct responds to any apoptotic signal, TG27 mice were injected with dexamethasone that induces thymus involution. The treatment resulted in elevated tissue transglutaminase activity (Figure $1 \mathrm{~A}$ ), increased levels of $\beta$-galactosidase mRNA detected by semiquantitative RT-PCR (Figure 1B)
A

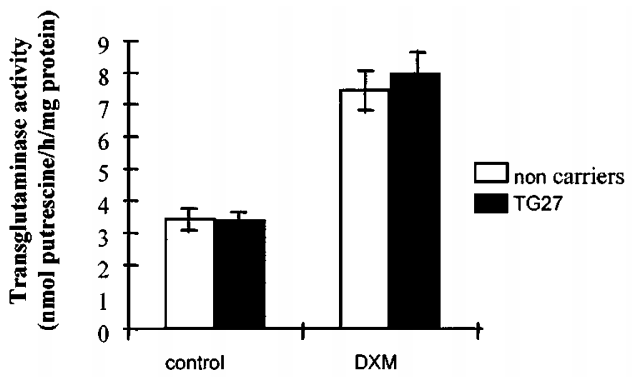

B
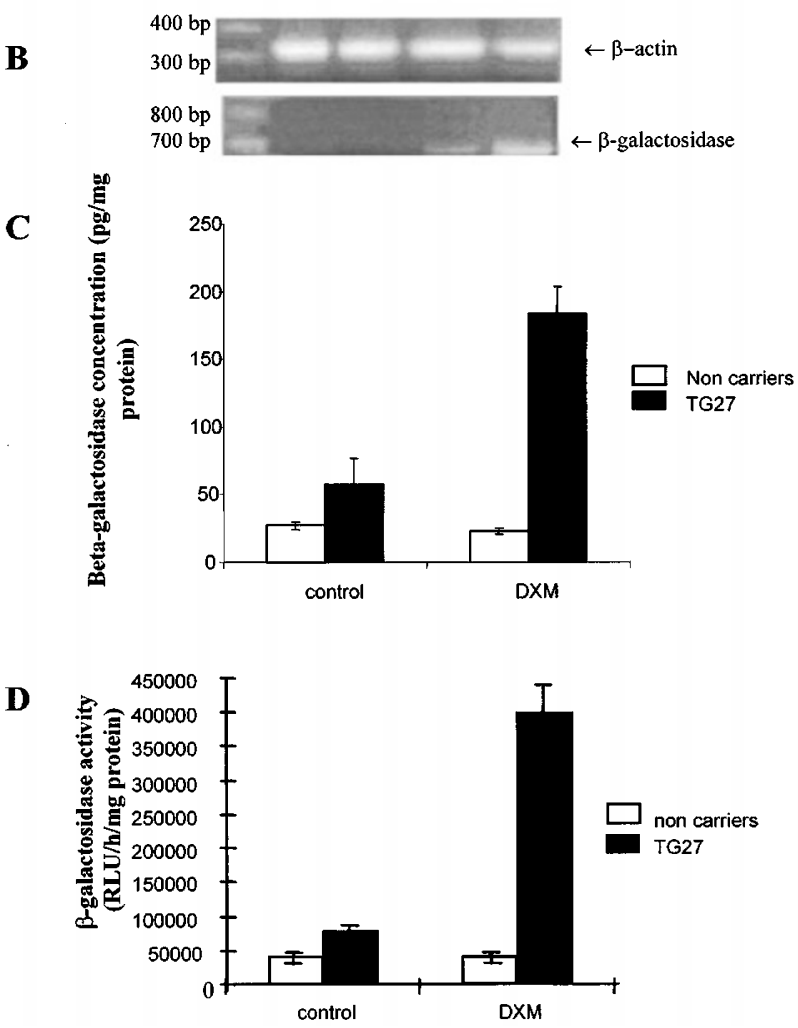

Figure 1 Activity of the reporter construct in normal thymus and during dexamethasone induced involution in transgenic mice. Four-week old transgene carrying mice (TG27) and their negative littermates were injected with $0.4 \mathrm{mg}$ dexamethasone in physiological saline or only with the vehicle as controls. Thymus was removed $24 \mathrm{~h}$ after treatment and total RNA was isolated or tissue lysate was made for determining enzyme activities or protein amount. (A) Transglutaminase activities in normal and involuting thymus. (B) mRNA levels in normal and involuting thymus detected by semiquantitative RT-PCR. The LacZ and $\beta$-actin mRNA transcripts were copied to cDNA and then amplified in a PCR reaction using total RNA. Lanes: (1) untreated negative littermate, (2) dexamethasone treated negative littermate, (3) untreated TG27 mouse, (4) dexamethasone treated TG27 mouse. (C) Concentration of $\beta$-galactosidase in normal and involuting thymus detected by ELISA technique. (D) Reporter enzyme activity in untreated and dexamethasone treated thymus. Bars represent mean values of three independent experiments; standard deviations are indicated

and protein (Figure 1C), and a 5.5 times higher activity compared to untreated littermates (Figure 1D).

\section{Apoptosis linked expression}

To further study the possible link between apoptosis and the expression of the transgene construct, systematic 
investigation of three different in vivo apoptosis systems was initiated. One of the risks of transgene studies is the misintegration of the construct. To eliminate possible effects of the transgene integration site on the promoter activation, two separate founder lines (TG26, TG27) were examined.

\section{Thymus involution}

Apoptosis plays an essential role in shaping the T lymphocyte repertoire. Immature T-cells are susceptible to various apoptotic signals including (a) dexamethasone, a ligand for the glucocorticoid receptor; ${ }^{5}$ (b) anti-CD3 monoclonal antibody that activates the TCR (T-cell receptor) mediated pathway involving nur77; ${ }^{20}$ (c) irradiation that causes DNA damage and switches on $p 53,^{8}$ (d) CD437 that acts on the retinoic acid receptor $(\mathrm{RAR}) \gamma^{7}$ and (e) anti-Fas antibody that crosslinks the Fas receptor. ${ }^{21}$ In earlier studies transglutaminase was found to be induced as a consequence of all the aforementioned apoptotic signals except Fas stimulation. ${ }^{21}$ In the present experiments the effect of these signals was tested on the thymic apoptotic program of the TG26 and TG27 mice. Similarly to dexamethasone, all of these signals led to significant involution of the thymus within $24 \mathrm{~h}$ (Figure $2 \mathrm{~A}$ ). The changes in the $\beta$-galactosidase activities were compared to that of the endogenous tissue transglutaminase. Figure $2 \mathrm{~B}$ shows that in case of the TG27 strain 5.5, 4.5, 5.2 and 4.2-fold increases of $\beta$-galactosidase activity were detectable following dexamethasone treatment, irradiation, anti-CD3 treatment and CD437 injection, respectively; while no significant change was measured in the case of anti-Fas antibody. These data correlate well with changes in the activity of the endogenous tTG: 2.7, 4.3, 5.3, 4.6-fold increase detected in case of dexamethasone treatment, irradiation, anti-CD3 and CD437 injection, respectively, while no increase following anti-Fas antibody treatment (Figure 2C). Thymic samples of the TG26 mice followed this pattern, however in a less pronounced manner $(3.4,2.3,2.9$ and 1.6-fold increase in the reporter enzyme activity, respectively).

\section{In vitro apoptosis of thymocytes}

Since mouse thymocytes can be easily isolated and induced to die in vitro by all the stimuli used in vivo, it was investigated, whether endogenous tTG or the reporter gene also responds to the apoptotic signals during in vitro apoptosis induction. Thymocytes were induced to die by $10 \mu \mathrm{g} / \mathrm{ml}$ coated anti-CD3 antibody, $1 \mu \mathrm{M}$ dexamethasone-acetate, $1 \mu \mathrm{M}$ CD437 and by $5 \mathrm{~Gy}$ of irradiation. The development of apoptosis was followed by detecting the amount of DNA fragmented, which was $39.5 \pm 5.8,58.8 \pm 5.8,71.2 \pm 5.4$ and $75.6 \pm 3.2 \%$ at $6 \mathrm{~h}$ after anti-CD3, dexamethasone, CD437 treatment and irradiation, respectively. Despite of the development of the apoptosis no increases in the tTG and $\beta$-galactosidase activities were detected (data not shown).

\section{Mammary gland}

The mammary gland undergoes a reproductive remodelling termed involution following the removal of the suckling
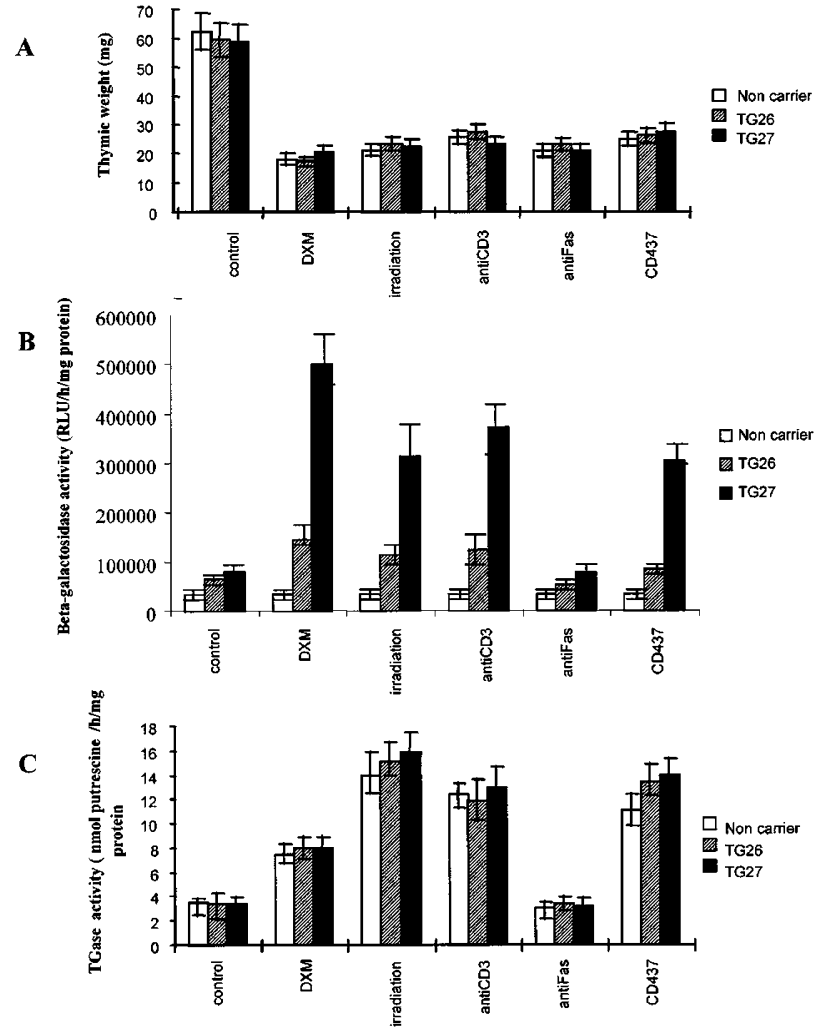

Figure 2 Changes in the tissue transglutaminase and $\beta$-galactosidase activities in response to various apoptotic signals in thymus. TG26, TG27 and negative mice were treated with $0.4 \mathrm{mg}$ dexamethasone, 5 Gy $\gamma$-irradiation, $20 \mu \mathrm{g}$ anti-CD3 mAb, $9 \mu \mathrm{g}$ anti-Fas mAb, $0.3 \mathrm{mg}$ CD437 RAR $\gamma$ analogue or injected only with vehicle as controls. The involution and the enzyme activities were detected $24 \mathrm{~h}$ after injection. Bars represent means of triplicates; the standard deviations are indicated. (A) thymic involution, (B) $\beta$-galactosidase activities and $(\mathbf{C})$ transglutaminase activities

stimulus at weaning. This process is initially characterised by a rapid decrease in milk synthesis, followed by programmed cell death of the secretory epithelial cells ${ }^{22,23}$ and proteolytic degradation of the extracellular matrix. The induction of tTG was reported to be part of the death program of the secretory epithelial cells. ${ }^{24}$

To examine whether the promoter fragment of our transgene construct is able to direct the $\beta$-galactosidase induction in this physiological apoptosis, the reporter enzyme activity was measured during lactation and at 3 , 6 and 9 days after weaning in TG26 and TG27 mice. Figure 3 shows that there was almost no activity in the lactating gland, while 5.79 and 13.4 times higher activity was measurable at day 3 of involution and a reduced but still 3.03 and 7.3-fold higher activity was detected at the 6th day after weaning in the TG26 and TG27 strains, respectively. At day 9 the activity returned to the basic value detected in the lactating mammary gland in both strains.

To further examine the expression of the transgene construct $\beta$-galactosidase enzyme histochemistry was performed using $X$-gal substrate (Figure 4). While there was no detectable level of $\beta$-galactosidase in the lactating gland (Figure $4 \mathrm{~A}$ ), at day 3 after weaning the strong blue 
staining in the epithelial cells demonstrated that the promoter was switched on and $\beta$-galactosidase was expressed (Figure 4B). The intensity of the staining decreased in a restricted but similar pattern by day 6 of involution (Figure 4C). To verify that the dying cells are the ones that express the $\beta$-galactosidase enzyme, the $\mathrm{X}$-gal enzyme histochemistry was followed by a terminal uridine

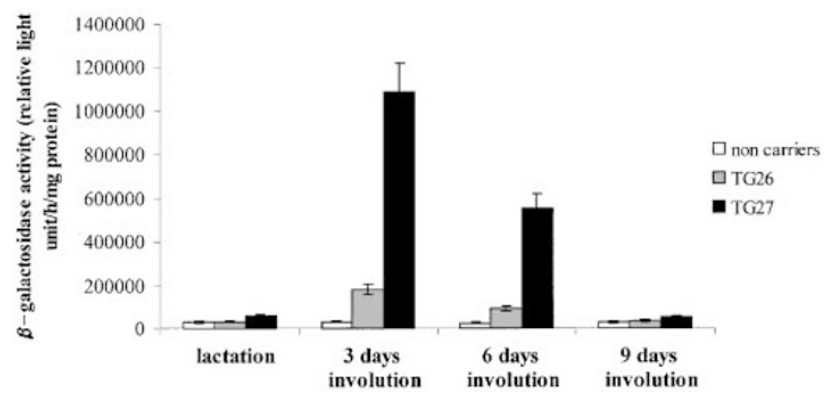

Figure 3 Transgene directed $\beta$-galactosidase activities in the lactating and in the involuting mammary gland in TG26 and TG27 mice. The fourth inguina mammary gland was removed at lactation, 3, 6 and 9 days postweaning, homogenised and the $\beta$-galactosidase activity was determined. Bars represent means of triplicates; standard deviations are indicated nucleotide end labelling (TUNEL) reaction at day 3 of involution. The blue product produced by the expressed $\beta$ galactosidase in the rings of dying secretory epithelial cells demonstrated good correlation with the distribution of the brown apoptotic nuclei (Figure 4D). Sixty-seven per cent of the cells in the section showed TUNEL positivity, $86 \%$ of these TUNEL positive cells expressed the $\beta$-galactosidase and $14 \%$ of the cells were single positive for the reporter enzyme. In agreement with our previous observation the single $\beta$-galactosidase positive cells very likely represent the early apoptotic cells in which the tTG upregulation precedes the degradation of nuclei. ${ }^{21}$

\section{Ovary}

In the luteal phase of the ovarian cycle there is vascularisation and hypertrophy in the luteal cells. If the egg is fertilised, the luteal cells proliferate longer and produce progesterone. The luteolysis-the structural and functional regression of the corpus luteum-begins sometime between day 16 of pregnancy and the day of parturition. It has been reported that the luteal cells die by programmed cell death during luteolysis and gonadotropins are survival factors for these cells. $^{25}$ a

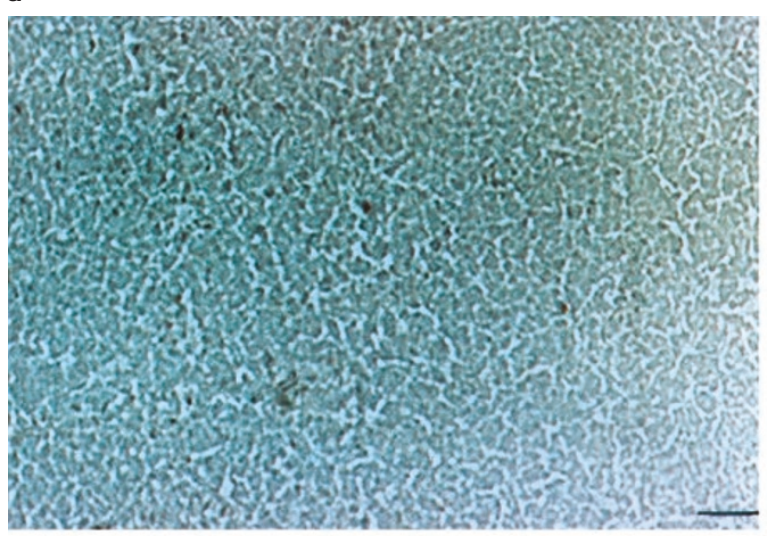

C

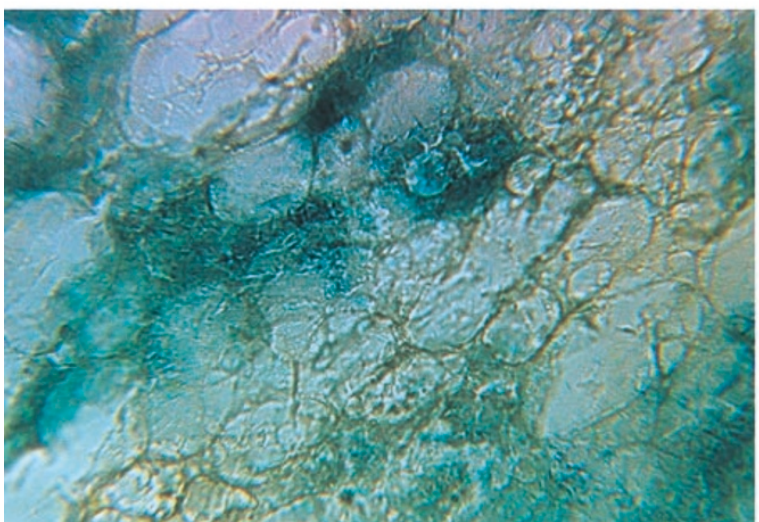

b

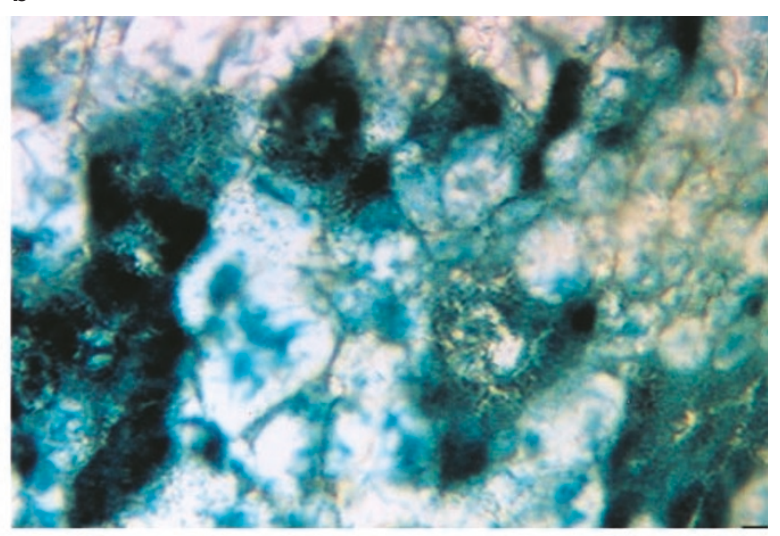

d

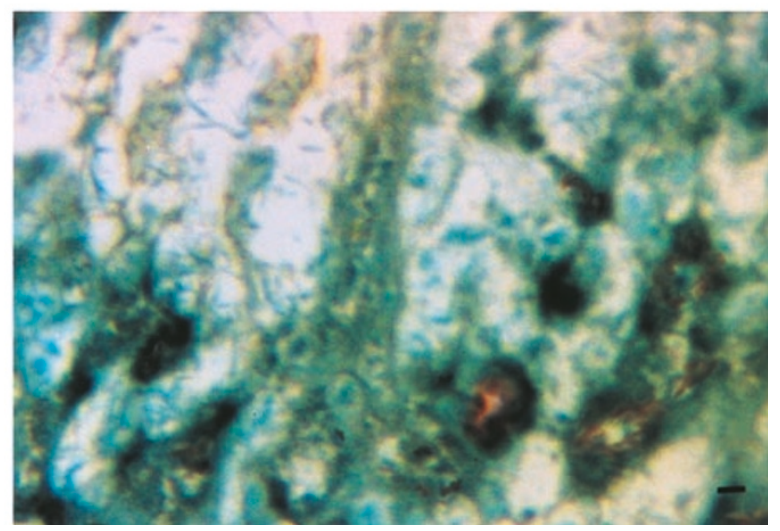

Figure 4 Histological detection of transgene directed $\beta$-galactosidase activity and apoptosis during mammary gland involution in TG27 mice. On frozen sections of mammary gland X-gal enzyme histochemistry was carried out. The blue reaction product reflects the enzyme expression in the dying epithelial cells (A) in lactating gland (bar: $100 \mu \mathrm{m})$, (B) at day 3 and (C) at day 6 of mammary gland involution. (D) Co-localisation of $\beta$-galactosidase expression with the brown apoptotic nuclei detected by TUNEL technique. Bars: $10 \mu \mathrm{m}$ 
In our experiments it was addressed whether the transgene construct directs the induction of the reporter enzyme during luteolysis in the TG26 and TG27 mice. The measurement of $\beta$-galactosidase activity revealed that during pregnancy almost no activity was detectable. At the day of parturition this value was increased by 4.8 times, after 3 days of parturition the activity had a peak with 9.7 times increase and at day 6 increased enzyme expression was not detectable in TG27 mice (Figure 5). $\beta$-galactosidase activities of the TG26 strain followed this pattern but in a restricted scale. At the day of parturition the activity increased to $153 \%$ of the activity measured during pregnancy, by day 3 after parturition this value further increased to $257 \%$ and at day 6 the activity decreased back to a value not significantly different from activity measured during pregnancy. Similar pattern was produced by X-gal enzyme histochemistry made on the TG27 strain (Figure 6). No staining was visible at day 14 of pregnancy (Figure 6A). The expression became apparent at the day of parturition (Figure 6B) that further intensified by the third day postpartum (Figure $6 \mathrm{C})$. There was no detectable $\beta$-galactosidase activity at day 6 . The co-localisation of the apoptotic cells and the reporter expressing cells was also examined and it revealed that the dying cells contained the product of the LacZ gene (Figure 6D): $43 \%$ of the cells showed the brown colour of the TUNEL staining, $83 \%$ of these cells was positive for X-gal staining and only $5 \%$ of the cells was $\beta$-galactosidase positive without a positive TUNEL reaction.

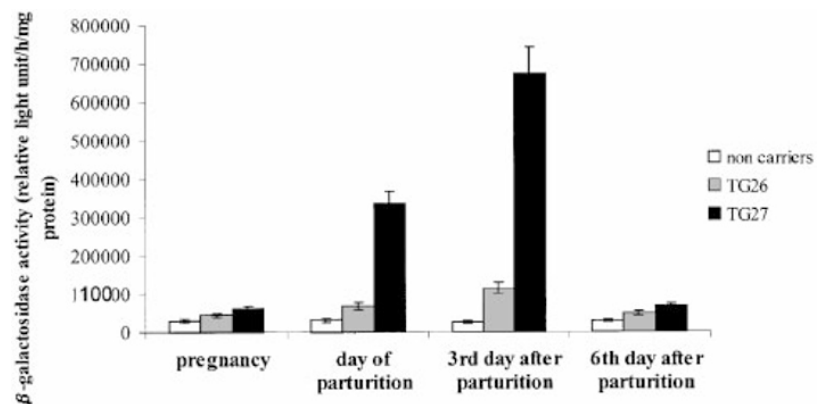

Figure 5 Bacterial $\beta$-galactosidase activities in the ovary during pregnancy and after parturition in TG26 and TG27 mice. Ovary was removed at day $14 \mathrm{o}$ pregnancy, at the day of parturition, and at 3 and 6 days after parturition, homogenised and $\beta$-galactosidase activity was determined. Bars represent means of three animals; standard deviations are indicated a

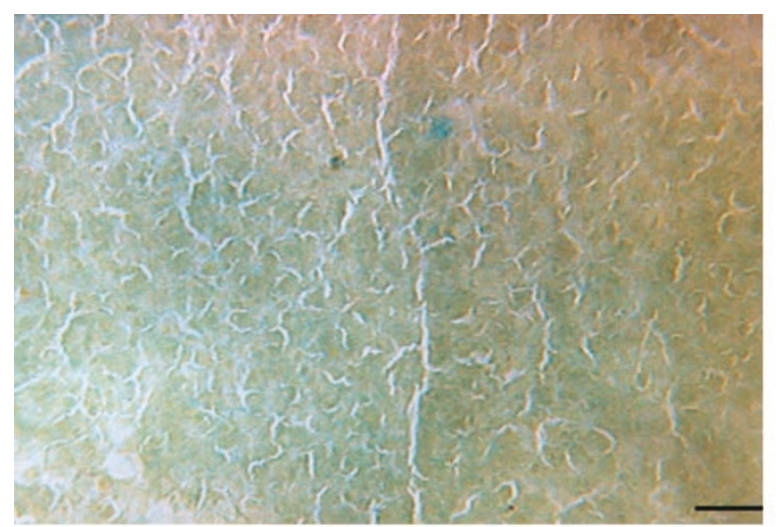

C

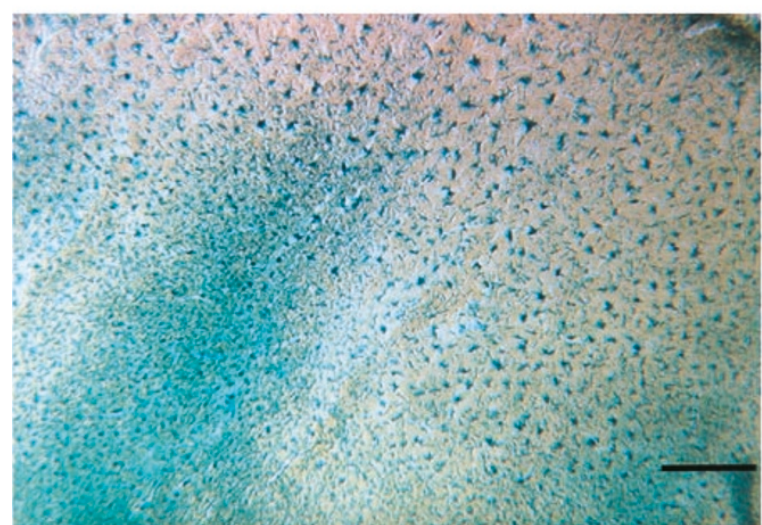

b

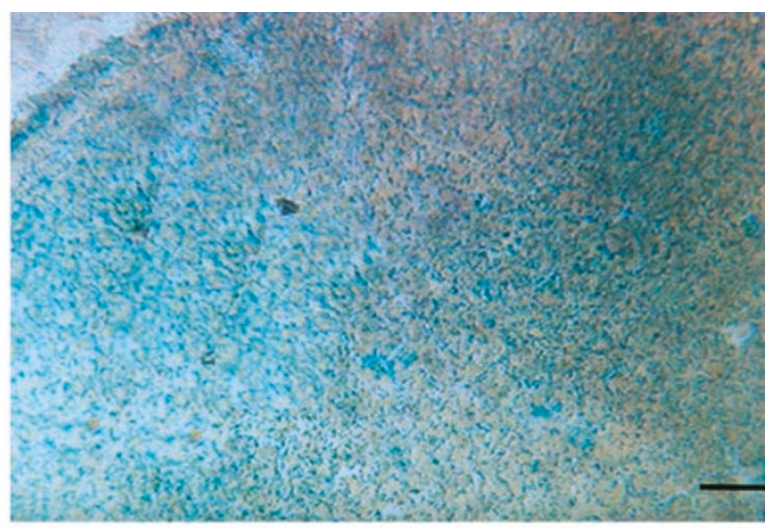

d

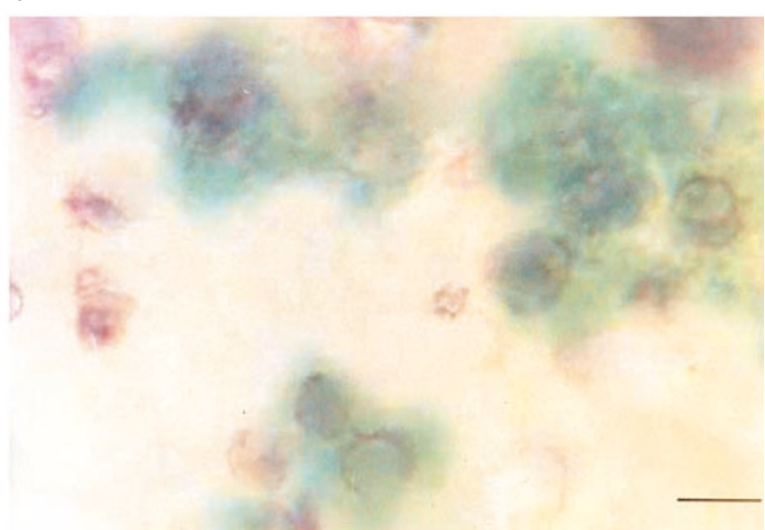

Figure 6 Histological detection of transgene directed $\beta$-galactosidase activity and apoptosis during corpus luteum regression in TG27 mice. Blue staining reflects $\beta$-galactosidase activity, while brown reaction product represents apoptotic nuclei. (A) No staining is detectable at day 14 of pregnancy, (B) minimal blue staining is visible in the ovary at the day of parturition (bar: $50 \mu \mathrm{m}$. (C) Conspicuous $\beta$-galactosidase reactivity at day 3 postpartum (bar: $50 \mu \mathrm{m}$ ). (D) Co-localisation of the $\beta$ galactosidase expression with the apoptotic nuclei detected by TUNEL technique in the luteal cells at day 3 postpartum. Bars: $20 \mu \mathrm{m}$ 


\section{Tissue specific expression}

To determine whether the elements of the $3.8 \mathrm{~kb} 5$ flanking segment of the mouse tissue transglutaminase gene are sufficient to drive the tissue specific expression in adult animals, the activity of the coupled $\beta$-galactosidase was measured in various tissues of TG26 and TG27 mice and was compared to that of the endogenous tissue transglutaminase. As shown in Table 1, endogenous tTG activity was detected in most of the examined tissues. The tissue specific distribution of the reporter gene showed the same pattern in both the TG26 and the TG27 mice, however TG26 mice displayed generally lower activities in all the examined tissues. $\beta$-galactosidase activity was detectable in thymus, spleen and in small intestine, tissues characterised by high endogenous apoptotic turnover, and in kidney where the final stage of differentiation with high rate of apoptosis was reported in 4 weeks old mice. ${ }^{26}$ The brain, lungs, heart and liver on the other hand failed to show significant reporter enzyme activity. Comparison of the $\beta$-galactosidase activities to the endogenous tTG activity revealed that the low $\beta$ galactosidase activity found in brain correlated with the low endogenous tTG activity, while no correlation was found in the case of lungs, heart and liver.

To exclude the possibility that the observed differences in the enzyme activities are related to a possible tissue specific difference in the turnover of the two proteins, a semiquantitative RT-PCR was carried out to detect the mRNA of the $\beta$-galactosidase construct. As shown in Figure 7 high levels of $\beta$-galactosidase mRNA were detected in tissues with high $\beta$-galactosidase activity, faint level was found in the lungs, while no mRNA was detected in the brain, liver and heart. These data suggest that the observed difference between the activities of the endogenous enzyme and $\beta$-galactosidase is not related to different protein turnover rates but rather reflects the lack of transcriptional response of the $3.8 \mathrm{~kb}$ fragment of the tTG promoter.

The parallelism of the data resulted from the study of the two founder lines (TG26, TG27) in all the three examined tissues proves that the transgene construct showed a specific response that cannot result from positional effects caused by the random insertion of the promoter structure.

\section{Discussion}

Intense research of the past few years has described many aspects of the biochemical program of apoptosis. However, most of our understanding derives from cells that are easy to maintain in culture such as cells of haematopoetic origin and malignant cell lines. There is an increasing concern in the field that these cell cultures do not mimic the whole biological program of apoptosis manifested in the context of a tissue environment. ${ }^{27} \mathrm{~A}$ good example for the discrepancy between the in vivo and in vitro apoptotic program is the behaviour of tissue transglutaminase. While the enzyme was shown to be induced in various apoptotic systems in vivo, ${ }^{18}$ many cells fail to upregulate tTG during apoptosis in vitro. ${ }^{28}$ That is why we have decided to study the apoptotic regulation of tTG under in vivo conditions using the transgene strategy.

At least three regulatory processes appear to contribute to the control of tissue transglutaminase expression in vivo. A distinct pattern of tissue specific expression, ${ }^{13}$ regulation by retinoids ${ }^{29}$ and induction of apoptosis by various signals. ${ }^{30-32}$ In our studies models in which transcription factors responsible for apoptosis induction have already been described were selected. In the thymus stimulation of TCR-associated CD3 molecule with a specific antibody, ${ }^{33}$ high levels of glucocorticoids, ${ }^{5}$ treatments leading to DNA breaks - such as ionising radiation, ${ }^{34}$ retinoids $^{7}$ and crosslinking of the Fas receptor ${ }^{21}$ all induce apoptosis. The

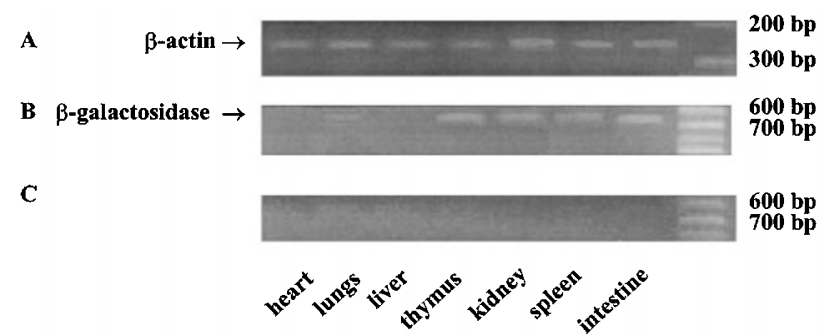

Figure 7 Transgene derived mRNA levels in various tissues of the TG27 mice. The $L a c Z$ and $\beta$-actin mRNA transcripts were copied to cDNA and then amplified in a PCR reaction using total RNA isolated from the tissues (lungs, liver, thymus, kidney, spleen, small intestine, heart and brain) of TG27 mice. (A) $\beta$-actin expression, (B) $\beta$-galactosidase expression and (C) mock PCR for $\beta$-galactosidase done by omitting the reverse transcription

Table 1 Tissue transglutaminase and $\beta$-galactosidase activities in tissues of 4-week-old TG26 and TG27 mice and non carrier littermates. The enzyme activities were measured in tissue homogenates as described in Materials and Methods

\begin{tabular}{|c|c|c|c|c|}
\hline \multirow[b]{2}{*}{ Tissue } & \multirow{2}{*}{$\begin{array}{l}\text { Transglutaminase activity } \\
\text { (nmol putrescine/h/mg prot. }\end{array}$} & \multicolumn{3}{|c|}{$\beta$-galactosidase activity (RLU/h/mg protein) $\times 10^{-3}$} \\
\hline & & Non carriers & TG26 strain & TG27 strain \\
\hline Thymus & $3.7 \pm 1.1$ & $46.7 \pm 18.7$ & $72.0 \pm 14.3^{*}$ & $110.0 \pm 29.8^{*}$ \\
\hline Lung & $13.3 \pm 3.4$ & $67.7 \pm 18.9$ & $73.8 \pm 18.1$ & $85.8 \pm 7.1$ \\
\hline Liver & $28.7 \pm 5.4$ & $56.2 \pm 6.3$ & $66.1 \pm 5.1$ & $75.1 \pm 11.8$ \\
\hline Kidney & $35.7 \pm 8.7$ & $54.5 \pm 14.8$ & $91.3 \pm 4.1^{*}$ & $110.5 \pm 7.5^{\star}$ \\
\hline Spleen & $11.7 \pm 3.7$ & $55.9 \pm 8.3$ & $78.9 \pm 2.2^{*}$ & $83.9 \pm 2.1^{*}$ \\
\hline Brain & $0.9 \pm 0.2$ & $59.1 \pm 7.2$ & $64.3 \pm 5.3$ & $68.1 \pm 6.3$ \\
\hline Intestine & $4.3 \pm 1.1$ & $60.1 \pm 3.2$ & $87.5 \pm 6.2^{*}$ & $174.2 \pm 17.4^{*}$ \\
\hline Heart & $3.6 \pm 0.8$ & $45.1 \pm 7.2$ & $39.8 \pm 6.1$ & $46.4 \pm 5.7$ \\
\hline
\end{tabular}

*Significantly different from the littermate which does not carry the transgene by student $t$-test $(P<0.05)$. Data represent mean \pm S.D. of three determinations 
apoptotic program induced in each of these cases work via different signal transduction pathways. Stimulation of TCR and CD3 induces changes in second messenger systems, glucocorticoids bind to steroid receptors, retinoids are ligands for the $\operatorname{RAR} \gamma$ receptor, crosslinking of Fas initiates caspase activation, ${ }^{35}$ while DNA damage induces protein phosphorylation. $^{36}$ Each of these pathways appears to utilise different sets of transcription factors with the exception of the Fas system where no new protein synthesis is required. Glucocorticoid and retinoid receptors belong to the zinc finger nuclear receptor family. The immediate-early gene, nur77, and AP-1 are induced in response to TCR signals. ${ }^{20,37}$ DNA damage leads to $p 53$ induction which is essential to transmit the lethal effect of ionising radiation. ${ }^{8,38}$ Nuclear accumulation of $p 53$ has also been reported in the luteal cells of ovary destined to die. ${ }^{39}$ Involution of the mammary gland, on the other hand, seems to be mediated via AP-1 bound transcription factors. The program is initiated by the lack of the suckling stimulus that activates PKA and increases the DNA binding activity of $A P-1$ followed by the expression of various $A P-1$ regulated proteins involving the $\mathrm{c}$-fos, junD, c-jun, transforming growth factor- $\beta 1$, gas- 1 and stromelysin 1 . $^{23,40,41}$

The data presented in this study demonstrate that the transgene derived from the TTG promoter is induced in each of the studied in vivo apoptotic system where the requirement for new protein synthesis has been reported proving that transcriptional regulation of tTG expression is part of the in vivo apoptotic program of many cell types. On the other hand, neither the endogenous tTG nor $\beta$ galactosidase activities were induced by the Fas system that was shown to be independent from new protein synthesis. The fact that the promoter of tTG was able to drive the expression of the reporter enzyme during apoptosis induced by such a wide array of apoptotic stimuli suggests that the $3.8 \mathrm{~kb}$ fragment of the tTG promoter contains all the cis acting elements required to drive apoptosis specific expression in vivo.

From these potential response elements in the promoter of tTG the retinoid response element is the only one which has been characterised so far and was found to be within the $3.8 \mathrm{~kb}$ fragment of the promoter. ${ }^{42}$ In the mouse promoter no consensus glucocorticoid, nur77 or p53 response elements have been found, but the human promoter was shown to contain one potential glucocorticoid response element (TGTACAGCTTGTTCT) and one potential AP1-binding site (TGTGTCAG) within the $1.7 \mathrm{~kb}$ upstream DNA segment. ${ }^{43}$ By sequence comparison there are three potential AP-1 sites located in the $3.8 \mathrm{~kb}$ fragment of the mouse promoter. Detailed studies have revealed that one of them is active during mammary gland involution (Gaal and Fesus, unpublished results) suggesting direct regulation of the transglutaminase promoter by $\mathrm{AP}-1$ complexes. Induction of endogenous tTG following irradiation seems to be p53 dependent, since no induction of the enzyme was observed in the $p 53-/-$ mice (Szondy and Wyllie, unpublished observations).

It was surprising to find that while all the above mentioned signals were capable to drive the transgene expression during thymic involution in vivo, neither the endogenous tTG nor $\beta$-galactosidase activities were induced during in vitro apoptosis of thymocytes. These observations suggest that factors available only in a tissue context are necessary for the upregulation of the tissue transglutaminase. Since thymocytes could enter the apoptotic program under in vitro conditions even in the absence of the induction of the enzyme, our observations also suggest that its in vivo role may not be directly related to the molecular events of killing, but rather to those occurring only in vivo such as phagocytosis or tissue remodelling. To support this hypothesis tTG has been reported to be externalised from cells and to modify the extracellular matrix. ${ }^{14,15}$ Alternatively various signal transduction pathways for death are initiated under in vivo and in vitro conditions and one of them involves tTG, while others do not.

Our reported data show that while there is a general agreement between the expression of the transgene and endogenous transglutaminase in tissues characterised by high apoptotic turnover, there are sites where such parallelism cannot be found. Endogenous tTG is expressed in heart and liver but we detected no evidence of the transgene expression in either of these tissues. Neither was expression of the transgene construct found in these tissues during embryogenesis. ${ }^{19}$ These observations suggest that the $3.8 \mathrm{~kb}$ tTG promoter lacks sequences present in the endogenous gene that are necessary for the specific expression of tTG in these tissues. They also implicate that the cis-regulatory sequences necessary for the expression of tTG in apoptotic cells are different from those regulating the expression of the enzyme in parenchymal tissue such as liver and heart.

\section{Materials and Methods}

\section{Experimental animals}

Two founder lines (TG26 and TG27) of a transgenic mouse strain carrying the 3.8 kilobase long proximal fragment of the tissue transglutaminase gene coupled with bacterial $\beta$-galactosidase reporter enzyme characterised previously ${ }^{19}$ were used in the experiments. The transgene carrying individuals were selected by PCR (polymerase chain reaction) detecting the lacZ gene. Apoptosis was induced by intraperitoneal injection of $0.3 \mathrm{mg}$ dexamethasoneacetate, $0.4 \mathrm{mg}$ CD437 (6-(3-(1-Adamanthyl)-4-hydroxyphenyl)-2naphtoic acid), $20 \mu \mathrm{g}$ anti-CD3 (clone: 145-2C11), $9 \mu \mathrm{g}$ anti-Fas (Jo2) monoclonal antibodies or by irradiation (5 Gy).

\section{Cell culture with thymocytes}

To follow the in vitro regulation of tTG and the reporter gene, thymocytes of 4-week-old mice were isolated and cultured by mincing the glands in RPMI 1640 media (Sigma Chemical) supplemented with $10 \%$ foetal calf serum (GIBCO, Grand Island, NY), $2 \mathrm{mM}$ glutamine, penicillin and streptomycin. Thymocytes were washed three times and diluted to a final concentration of $10^{7}$ cells $/ \mathrm{ml}$ before incubation at $37^{\circ} \mathrm{C}$ in a humidified incubator under an atmosphere of $5 \% \mathrm{CO}_{2} / 95 \%$ air. Cell death was measured by trypan blue uptake. A total of $95-$ $98 \%$ of cells routinely excluded trypan blue after the isolation procedures. Thymocytes were induced to die in 24-well plates by $10 \mu \mathrm{g} / \mathrm{ml}$ coated anti-CD3 antibody, $1 \mu \mathrm{M}$ dexamethasone-acetate, 
$1 \mu \mathrm{M} \mathrm{CD} 437$ or by 5 Gy of irradiation. After $6 \mathrm{~h}, 0.8 \mathrm{ml}$ of cell suspension was lysed by the addition of $0.7 \mathrm{ml}$ of ice-cold lysis buffer containing $0.5 \%(\mathrm{v} / \mathrm{v})$ Triton $\mathrm{X}-100,10 \mathrm{mM}$ Tris and $20 \mathrm{mM}$ EDTA (ethylene diamine tetraacetate), $\mathrm{pH}$ 8.0. Then the samples were centrifuged for $15 \mathrm{~min}$ at $13000 \times \mathrm{g}$. DNA of the supernatants (DNA fragments) and pellets (intact chromatin) were prepared for determination of DNA fragmentation by diphenylamine reagent and for DNA agarose electrophoresis as described previously. ${ }^{44}$ The degree of fragmentation correlated well with the number of trypan blue positive dead cells throughout the experiments.

\section{Polymerase chain reaction (PCR)}

The transgene carrying mice were identified by amplifying a fragment of the reporter gene. A piece of tails of 3-week-old mice was cut and digested overnight at $60^{\circ} \mathrm{C}$ in $1 \mathrm{mg} / \mathrm{ml}$ proteinase $\mathrm{K}, 500 \mathrm{mM}$ Tris, $100 \mathrm{mM}$ EDTA, $100 \mathrm{mM} \mathrm{NaCl}$ and $1 \%$ sodium dodecyl sulphate. The DNA from the homogenate was isolated by a phenol:chloroform:isoamylalcohol $(24: 24: 1)$ and a chloroform:isoamylalcohol $(24: 1)$ extraction. One microgram of the genomic DNA was used for the PCR reaction $\left(1.5 \mathrm{mM} \mathrm{MgCl}_{2}, 2 \mathrm{mM}\right.$ of each dNTP (deoxynucleotide triphosphate), 1 unit Taq polymerase, $10 \mathrm{mM}$ Tris- $\mathrm{HCl}, 50 \mathrm{mM} \mathrm{KCl}, 0.1 \%$ Triton X-100, pH 9.0). A 680 bp long fragment of the $\beta$-galactosidase was amplified in 30 cycles with the following parameters: $94^{\circ} \mathrm{C}$ denaturation, $55^{\circ} \mathrm{C}$ annealing and $72^{\circ} \mathrm{C}$ chain extension, for $1 \mathrm{~min}$ each. Primers: upstream primer: $5^{\prime}$ TGA TCC TCG CTT GAG TCT CC; downstream primer: 5'-ATA ATT CGC GTC TGG CCT TC.

\section{Tissue transglutaminase activity measurement}

Thymus was collected from treated or control animals at $24 \mathrm{~h}$ after treatment, washed with PBS (phosphate buffered saline) and homogenised in $0.1 \mathrm{M}$ Tris- $\mathrm{HCl}, \mathrm{pH} 7.5$, containing $0.25 \mathrm{M}$ sucrose, $0.5 \mathrm{mM}$ EDTA, $1 \mathrm{mM}$ phenyl methyl sulfonyl fluoride. Transglutaminase activity in homogenates was measured by detecting the incorporation of $\left[{ }^{3} \mathrm{H}\right]$ putrescine into $\mathrm{N}, \mathrm{N}^{\prime}$-dimethyl casein. The reaction mixture had $50 \mathrm{mM}$ Tris- $\mathrm{HCl}, \mathrm{pH} 8.3,5 \mathrm{mM} \mathrm{CaCl}_{2}, 30 \mathrm{mM}$ $\mathrm{NaCl}, 10 \mathrm{mM}$ DTT (dithiothreitol) $2.5 \mathrm{mg} / \mathrm{ml}$ caseine, $0.2 \mathrm{mM}$ $\left[{ }^{3} \mathrm{H}\right]$ putrescine and tissue homogenate containing $50 \mu \mathrm{g}$ protein. Enzyme activity was calculated as nmoles of $\left[{ }^{3} \mathrm{H}\right]$ putrescine incorporated into casein in $1 \mathrm{~h}$, by $1 \mathrm{mg}$ cellular protein.

\section{$\beta$-galactosidase activity measurement}

A luminometric method was used; $24 \mathrm{~h}$ after treatment thymi of treated and control animals were collected, washed in PBS. The lysis and the measurement were carried out according to the description of the Galacto-light chemiluminescent reporter assay kit (Tropix). After lysing the cells a $50-\mathrm{min}$ incubation at $48^{\circ} \mathrm{C}$ in the presence of protease inhibitors $(0.5 \mu \mathrm{g} / \mathrm{ml}$ leupeptin, $0.1 \mu \mathrm{g} / \mathrm{ml}$ chymostatin, $1.0 \mu \mathrm{g} / \mathrm{ml}$ aprotinin and $1 \mathrm{mM}$ phenyl methyl sulfonyl fluoride) was included in the procedure in order to inactivate the endogenous $\beta$-galactosidases. ${ }^{45}$ The enzyme activity was expressed in RLU (relative light unit)/h/mg protein.

\section{$\beta$-galactosidase ELISA}

Twenty-four hours after treatment thymi of treated and control animals were collected, washed in PBS. Thymi were homogenised, and the $\beta$ galactosidase protein concentration was detected with the help of a $\beta$ galactosidase ELISA kit (Boehringer Mannheim), according to the manufacturer's instructions. $\beta$-galactosidase concentration was expressed as pg enzyme protein/mg total cellular protein.

\section{Reverse transcription-polymerase chain reaction (RT-PCR)}

The RT-PCR was performed from total RNA isolated with the Promega RNagent kit. cDNA synthesis: $2 \mu \mathrm{g}$ total RNA with the random hexamere primer, reverse transcriptase buffer (50 mM Tris$\mathrm{HCl}(\mathrm{pH} 8.3), 50 \mathrm{mM} \mathrm{KCl}, 10 \mathrm{mM} \mathrm{MgCl} 2,0.5 \mathrm{mM}$ spermidine and $10 \mathrm{mM}$ DTT) denatured at $70^{\circ} \mathrm{C}$ for $5 \mathrm{~min}$, then the reaction mixture was chilled on ice. Twenty units of AMV reverse transcriptase (Promega), $2.5 \mathrm{mM}$ of each dNTP and 40 units RNasin (Promega) were added (total volume was $25 \mu \mathrm{l}$ ) and the mixture was incubated at $42^{\circ} \mathrm{C}$ for $1 \mathrm{~h}$ to synthesise cDNA. Five microlitres of the cDNA was used to amplify the $\beta$-galactosidase and a $247 \mathrm{bp}$ region of the $\beta$-actin cDNA. The PCR conditions were the same as for the PCR of the genomic DNA, except the number of cycles that was 32. $\beta$-actin primers: upstream primer: $5^{\prime}$-TGC GTG ACT ACC TAC GGG TAA CAG T; downstream primer: 5'-GAT CGA CAG ATT TGA TCC AGC GAT A.

\section{X-gal enzyme-histochemistry}

After treatments $5 \mu \mathrm{m}$ thick frozen sections were made. Sections were fixed in $0.25 \%$ glutaraldehyde for $5 \mathrm{~min}$ at room temperature, the fixative was removed by washing three times with PBS, and then the staining solution $(0.2 \% \mathrm{X}$-Gal 5 -bromo-4-chloro-3-inodyl- $\beta$-D-galactosidase (stock: $20 \mathrm{mg} / \mathrm{ml}$ dimethylformamide), $1 \mathrm{mM} \mathrm{MgCl} 2$ (stock: $1 \mathrm{M}$ ), $150 \mathrm{mM} \mathrm{NaCl}$ (stock: $0.45 \mathrm{M}$ ), $33 \mathrm{mM} \mathrm{K} \mathrm{K}_{4} \mathrm{Fe}(\mathrm{CN})_{6} \times 3 \mathrm{H}_{2} \mathrm{O}$ (stock: $0.1 \mathrm{M}$ ), $33 \mathrm{mM} \mathrm{K} \mathrm{K}_{3} \mathrm{Fe}(\mathrm{CN})_{6}$ (stock: $\left.0.1 \mathrm{M}\right)$ ) was added. Specimens were incubated overnight in a humid chamber at $37^{\circ} \mathrm{C}$, after it the excess staining solution were rinsed with distilled water and the specimens were mounted.

\section{In situ apoptosis detection}

Five micron-thick frozen tissue samples were made and fixed in acetone (10 min, room temperature), washed in PBS. The washing was followed by a Proteinase $\mathrm{K}$ treatment $(20 \mu \mathrm{g} / \mathrm{ml}, 15 \mathrm{~min}$ at room temperature) and a $5 \mathrm{~min}$ hydrogen peroxide treatment. The sections were air dried, equilibrated and then incubated for $1 \mathrm{~h}$ at $37^{\circ} \mathrm{C}$ with terminal transferase (TdT) enzyme in the presence of digoxigenine labelled dUTP. The digoxigenine built in the fragmented DNA was detected by alkaline phosphatase conjugated antidigoxigenine antibody.

\section{Acknowledgements}

We thank Etelka Vida for her technical assistance and Gabor Molnar for his advice on the manuscript. This work was supported by research grants obtained from the Hungarian Research Fund OTKA T 029528 and T 022705 (Z Szondy), T29672 and FKFP 0634/99 (László Fésüs), additionally by grants of 1R01 CA76088 (P Davies) and FIRCA 1R03TW01146-01 (L Nagy). Éva Szegezdi was a recipient of Hungarian-Swiss bilateral research fund. László Nagy was a recipient of the Boehringer Ingdheim Fund Research Award.

\section{References}

1. Weil M, Jacobson MD, Coles HS, Davies TJ, Gardner RL, Raff KD and Raff MC (1996) Constitutive expression of the machinery for programmed cell death. J. Cell. Biol. 133: 1053-1059 
2. Ramdas J, Liu W and Harmon JM (1999) Glucocorticoid-induced cell death requires autoinduction of glucocorticoid receptor expression in human leukemic T cells. Cancer Res. 59: 1378-1385

3. Imaizumi K, Morihara T, Mori Y, Katayama T, Tsuda M, Furuyama T, Wanaka A, Takeda M and Tohyama M (1999) The cell death-promoting gene DP5, which interacts with the BCL2 family, is induced during neuronal apoptosis following exposure to amyloid beta protein. J. Biol. Chem. 274: 7975-7981

4. Kojima S, Mayumi Matsuda K, Suzuki Hand Sakata T (1999) Molecularcloning of rat GADD45gamma, gene induction and its role during neuronal cell death. FEBS Lett. 446: 313-317

5. Cohen GM, Sun XM, Snowden RT, Ormerod MG and Dinsdale D (1993) Identification of a transitional preapoptotic population of thymocytes [published erratum appears in J. Immunol. 1993 Dec 1; 151(11): 6616]. J. Immunol. 151: $566-574$

6. Mihara S, Suzuki N, Wakisaka S, Suzuki S, Sekita N, Yamamoto S, Saito N, Hoshino T and Sakane T (1999) Effects of thyroid hormones on apoptotic cell death of human lymphocytes. J. Clin. Endocrinol. Metab. 84: 1378-1385

7. Szondy Z, Reichert U, Bernardon JM, Michel S, Toth R, Ajzner E, Ancian P and Fesus $L$ (1997a) Induction of apoptosis by retinoids and RAR y selective compounds in mouse thymocytes through a novel apoptosis pathway. Mol. Pharmacol. 51: $972-982$

8. Lowe SW, Schmitt EM, Smith SW, Osborne BA and Jacks T (1993) p53 is required for radiation-induced apoptosis in mouse thymocytes. Nature 362 847-849

9. Chin YE, Kitagawa M, Kuida K, Flavell RA and Fu XY (1997) Activation of the STAT signaling pathway can cause expression of caspase 1 and apoptosis. Mol. Cell Biol. 17: 5328-5337

10. Rauch F, Polzar B, Stephan H, Zanotti S, Paddenberg R and Mannherz HG (1997) Androgen ablation leads to an upregulation and intranuclear accumulation of deoxyribonuclease I in rat prostate epithelial cells paralleling their apoptotic elimination. J. Cell Biol. 137: 909-923

11. Folk JE (1980) Transglutaminases. Ann. Rev. Biochem. 49: 517-531

12. Aeschlimann D, Wetterwald A, Fleisch H and Paulsson M (1993) Expression of tissue transglutaminase in skeletal tissues correlates with events of terminal differentiation of chondrocytes. J. Cell Biol. 120: 1461-1470

13. Thomazy $V$ and Fesus $L$ (1989) Differential expression of tissue transglutaminase in human cells. An immunohistochemical study. Cell Tissue Res. 255: 215-224

14. Fesus L, Metsis ML, Muszbek L and Koteliansky VE (1986) Transglutaminasesensitive glutamine residues of human plasma fibronectin revealed by studying its proteolytic fragments. Eur. J. Biochem. 154: 371-374

15. Prince CW, Dickie D and Krumdieck CL (1991) Osteopontin, a substrate for transglutaminase and factor XIII activity. Biochem. Biophys. Res. Commun. 177: $1205-1210$

16. Nakaoka H, Perez DM, Baek KJ, Das T, Husain A, Misono K, Im MJ and Graham RM (1994) Gh: a GTP-binding protein with transglutaminase activity and receptor signaling function. Science 264: 1593-1596

17. Oliverio S, Amendola A, Di Sano F, Farrace MG, Fesus L, Nemes Jr Z Piredda L, Spinedi A and Piacentini M (1997) Tissue transglutaminase-dependent posttranslational modification of the retinoblastoma gene product in promonocytic cells undergoing apoptosis. Mol. Cell Biol. 17: 6040-6048

18. Piacentini M, Davies PJA and Fesus $L$ (1994) Tissue transglutaminase in cells undergoing apoptosis. Curr. Commun. Cell Mol. Biol. 8: 143-163

19. Nagy L, Thomazy VA, Saydak MM, Stein JP and Davies PJA (1997) The promoter of the mouse tissue transglutaminase gene directs tissue specific, retinoid regulated and apoptosis-linked expression. Cell Death Differ. 4: $534-$ 547

20. Liu ZG, Smith SW, McLaughlin KA, Schwartz LM and Osborne BA (1994) Apoptotic signals delivered through the T-cell receptor of a T-cell hybrid require the immediate-early gene nur77. Nature 367: 281-284

21. Szondy Z, MolnarP, Nemes Z, Boyiadzis M, Kedei N, Toth Rand Fesus L (1997b) Differential expression of tissue transglutaminase during in vivo apoptosis of thymocytes induced via distinct signalling pathways. FEBS Lett. 404: 307-313

22. Strange R, Li F, Saurer S, Burkhardt A and Friis RR (1992) Apoptotic cell death and tissue remodelling during mouse mammary gland involution. Development 115: $49-58$

23. Marti A, Jehn B, Costello E, Keon N, Ke G, Martin F and Jaggi R (1994) Protein kinase $A$ and AP-1 (c-Fos/JunD) are induced during apoptosis of mouse mammary epithelial cells. Oncogene 9: 1213-1223
24. Nemes Jr Z, Frii RR, Aeschlimann D, Saurer S, Paulsson M and Fesus L (1996) Expression and activation of tissue transglutaminase in apoptotic cells of involuting rodent mammary tissue. Eur. J. Cell Biol. 70: 125-133

25. Yoshimura Y, Hosoi Y, Atlas SJ, Ghodgaonkar R, Dubin NH, Dharmarajan AM and Wallach EE (1994) Inhibition of gonadotrophin-induced ovulation in rabbits by perfusion with dibutyryl CAMP via reduction of ovarian prostaglandin production. J. Reprod. Fertil. 101: 207-212

26. Sorenson CM, Padanilam BJ and Hammerman MR (1996) Abnormal postpartum renal development and cystogenesis in the bcl-2(-/-) mouse. Am. J. Physiol. 271: F184-F193

27. Lockshin RA, Osborne B and Zakeri Z (2000) Cell death in the third millennium. Cell. Death Differ. 7: 2-7

28. Lim SD, BaeSI, Kim IG, Park SC, Chung SI, Nomizu M, Kleinman HKand KimWH (1998) Tissue transglutaminase is not increased during apoptosis of HT-1080 human fibrosarcoma cells. Exp. Toxic. Pathol. 50: 79-82

29. Verma AK, Shoemaker A, Simsiman R, Denning M and Zachman RD (1992) Expression of retinoic acid nuclear receptors and tissue transglutaminase is altered in various tissues of rats fed with vitamin A deficient diet. J. Nutr. 122: 2144-2151

30. Fesus L, Thomazy V and Falus A (1987) Induction and activation of tissue transglutaminase during programmed cell death. FEBS Lett. 224: 104-108

31. Nagy L, Thomazy VA and Davies PJA (1994) Tissue transglutaminase: an effector in physiologic cell death. Cancer Bull. 46: 136-140

32. Fesus L, Madi A, Balajthy Z, Nemes Z and Szondy Z (1996) Transglutaminase induction by various cell death and apoptosis pathways. Experientia 52: $942-$ 949

33. Smith CA, Williams GT, Kingston R, Jenkinson EJ and Owen JJ (1989) Antibodies to CD3/T-cell receptor complex induce death by apoptosis in immature T cells in thymic cultures. Nature 337: 181-184

34. Osborne BA, Smith SW, Liu ZG, McLaughlin KA, Grimm L and Schwartz LM (1994) Identification of genes induced during apoptosis in T lymphocytes. Immunol. Rev. 142: 301-320

35. Ashkenazi A and Dixit VM (1998) Death receptors: signaling and modulation. Science 281: 1305-1308

36. Kharbanda S, Ren R, Pandey P, Shafman TD, Feller SM, Weichselbaum RR and Kufe DW (1995) Activation of the c-Abl tyrosine kinase in the stress response to DNA damaging agents. Nature 376: 785-788

37. Ivanov VN and Nikolic-Zugic J (1997) Transcription factor activation during signal-induced apoptosis of immature CD4(+)CD8(+) thymocytes. A protective role of c-Fos. J. Biol. Chem. 272: 8558-8566

38. Clarke AR, Purdie CA, Harrison DJ, Morris RG, Bird CC, Hooper ML and Wyllie AH (1993) Thymocyte apoptosis induced by p53-dependent and independent pathways. Nature 362: 849-852

39. Tilly KI, Banerjee S, Banerjee PP and Tilly JL (1995) Expression of the p53 and Wilms' tumor suppressor genes in the rat ovary: gonadotropin repression in vivo and immunohistochemical localisation of nuclear p53 protein to apoptotic granulosa cells of atretic follicles. Endocrinology 136: 1394-1402

40. Li F, Strange R, Friis RR, Djonov V, Altermatt HJ, Saurer S, Niemann $\mathrm{H}$ and Andres AC (1994) Expression of stromelysin-1 and TIMP-1 in the involuting mammary gland and in early invasive tumors of the mouse. Int. J. Cancer 59: $560-568$

41. Marti A, Feng Z, Altermatt HJ and Jaggi R (1997) Milk accumulation triggers apoptosis of mammary epithelial cells. Eur. J. Cell Biol. 73: 158-165

42. Nagy L, Saydak M, Shipley N, Lu S, Basilion JP, Yan ZH, Syka P, Chandraratna RA, Stein JP, Heyman RA and Davies PJ (1996) Identification and characterisation of a versatile retinoid response element (retinoic acid receptor response element-retinoid $X$ receptor response element) in the mouse tissue transglutaminase gene promoter. J. Biol. Chem. 271: 4355-4365

43. Lu S, Saydak M, Gentile V, Stein JP and Davies PJ (1995) Isolation and characterisation of the human tissue transglutaminase gene promoter. J. Biol. Chem. 270: 9748-9756

44. Szondy Z. (1994) Adenosine induces DNA fragmentation in human thymocytes by $\mathrm{Ca}^{2+}$ dependent mechanisms. Biochem. J. 304: 877-885

45. Young DC, Kingsley SD, Ryan KA and Dutko FJ (1993) Selective inactivation of eukaryotic beta-galactosidase in assays for inhibitors of HIV-1 TAT using bacterial beta-galactosidase as a reporter enzyme. Anal. Biochem. 215: 24-30 